\title{
Interactive E-Module Development through Chemistry Magazine on Kvisoft Flipbook Maker Application for Chemistry Learning in Second Semester at Second Grade Senior High School
}

\author{
Roza Linda ${ }^{*}$, Herdini $^{1}$, Ika Sulistya S1, Teja Pratama Putra1 \\ ${ }^{1}$ Program Studi Pendidikan Kimia, Jurusan Pendidikan Matematika dan IPA, Fakultas Keguruan dan Ilmu Pendidikan, Universitas Riau, \\ Pekanbaru, Indonesia \\ *Corresponding Author. roza.linda@lecturer.unri.ac.id
}

\begin{abstract}
This research is an innovative development on teaching materials in order to intensify the movement of "Satu Guru Satu Buku (SAGUSABU)" and to prepare skillful media users on mastering Information and Communication Technologies (ICT). The resulting prototype is an interactive e-module named Chemistry Magazine which have two editions: ionic equilibrium and $\mathrm{pH}$ of buffer solution and solubility equilibrium. Applying research and development study design with Plomp model, assessment and suggestion by validator team on material substance aspect, instructional design, display (visual communication) and software utilization using validation sheet are in valid category. Percentage of legality score by media validator is $91.70 \%$ for ionic equilibrium and $\mathrm{pH}$ of buffer solution edition; and $94.18 \%$ for solubility equilibrium edition, whereas by material validator is $93.75 \%$ and $94.45 \%$ on each. Users response score rate through questionnaire for teachers and students on ionic equilibrium edition and $\mathrm{pH}$ of buffer solution edition are $87.08 \%$ and $88.45 \%$; meanwhile $94,25 \%$ and $91,43 \%$ are obtained from solubility equilibrium edition.
\end{abstract}

Keywords Interactive e-Module, Chemistry Magazine, Kvisoft Flipbook Maker, Buffer, Solubility, Plomp Model

\section{INTRODUCTION}

Having a good teaching material is an essential point on acquiring chemistry, it can facilitate both teachers and students while in the learning process (Direktorat Pembinaan SMA, 2008). Teaching materials are the resources a teacher uses to deliver instruction. Each teacher requires a range of tools to draw upon in order to assist and support student learning. These materials play a large role in making knowledge accessible to a learner and can encourage a student to engage with knowledge in different ways. Since 2016, Ministry of Education and Culture has been promoted the motion called "Satu Guru Satu Buku (SAGUSABU) in order to improve teachers capability in producing paperwork. One of the examples is a module. Andi Zulkarnain, et al (2015) stated that a module is a learning tool that contains the materials, methods, limitations, and steps used systematically and appealing to achieve the expected competence according to the complexity level (Direktorat Pembinaan SMA, 2008).

Printed modules teaching material can be modified into a filled glossary magazines form, as has been done by Wulandari, Azrita, \& Hendri (2016). This breakthrough appear due to learners are accustomed to technological advances and it can be observed that learners have a better understanding on android system technology rather than the teacher itself (Syahrowardi \& Permana, 2016). This is in line with the aim of our national education which stated that chemistry learning is expected to deliver participants who are capable of using Information and Communication Technologies (ICT).

Chemistry Magazine is a teaching material in the form of interactive e-module. It can be accessed easily by students using computers and various types of gadgets anywhere and anytime. This module can be created using flipbook applications namely Kvisoft Flipbook Maker (Syamsurizal \& Chairani, 2015). This kind of practicality can enrich digital products such as texts, images, audio, videos, animations, flash and links (www.kvisoft.com, 2015).

Received: 9 September 2018

Revised: 13 December 2018

Published: 16 December 2018 
Two of the hardest discussion, based on student's difficulty; one is about ionic equilibrium and $\mathrm{pH}$ of buffer solution, and the other is solubility equilibrium; are considered as the proper material for e-module content. Those subjects require a thorough understanding of theory and analysis to solve the problems, as well as proficient in calculations because the basic concepts related to solubility are described in terms of mathematical equations.

Based on the explanation above, the research was conducted on the development of interactive e-module Chemistry Magazine by utilizing Kvisoft Flipbook Maker Application for chemistry learning on a second-grade senior high school in the course of the second semester.

\section{METHOD}

The research is held in Chemistry Education Study Program, Faculty of Teachers Training and Education, Riau University with trials in SMA Negeri 8 Pekanbaru, SMA Negeri 12 Pekanbaru and SMA Negeri 2 Bangkinang Kota. Interactive e-module Chemistry Magazine by utilizing Kvisoft Flipbook Maker application for chemistry learning on a second-grade senior high school in the course of the second semester is adopted from Plomp development model. Consisting of initial investigation phase, design phase, realization/construction phase, validation, trials, and revision phase, and implementation phase (Rochmad, 2012). The implementation phase is not done because the purpose of the research is limited to obtain output in the form of valid product based on material substance aspect, instructional design, display (visual communication) and software utilization.

Data gathering related to user's validity and responses to interactive e-module Chemistry Magazine was obtained in validation phase, experiment and improvement using

Table 1 Validity criteria

\begin{tabular}{ll}
\hline Percentage score $\mathbf{( \% )}$ & Validity criteria \\
\hline $75.00-100$ & Valid \\
$50.00-74.99$ & Valid Enough \\
$25.00-49.99$ & Less Valid \\
$0.00-24.99$ & Not Valid \\
\hline
\end{tabular}

Table 2 User response scoring guidelines

\begin{tabular}{ll}
\hline Statement of attitudes & Score \\
\hline Agree (S) & 4 \\
Quite Agree (CS) & 3 \\
Less Agree (KS) & 2 \\
Disagree (TS) & 1 \\
\hline
\end{tabular}

Table 3 Criteria for user response

\begin{tabular}{ll}
\hline Percentage (\%) & Criteria for user response \\
\hline $75.00-100$ & Very Good \\
$50.00-74.99$ & Good \\
$25.00-49.99$ & Less Good \\
$0.00-24.99$ & Not Good \\
\hline
\end{tabular}

research instrument in the form of validation sheet prepared by one media validator and two material validators along with rubrics and user response questionnaires by teachers and students.

The data collected is then analyzed by specific analytical techniques. Analysis of validity using the formulation by Rohmad, Suhandini, \& Sriyanto (2013). The data collected is then analyzed by specific analytical techniques. Analysis of validity using the formulation by Rohmad, Suhandini, \& Sriyanto (2013).

$$
\mathrm{P}=(\mathrm{n} / \mathrm{N}) \times 100 \%
$$

Explanation:

$$
\mathrm{P}=\text { Percentage score }(\%)
$$

$\mathrm{n}=$ Number of scores obtained

$\mathrm{N}=$ Maximum score

The percentages obtained are then converted to qualitative values with the validity criteria in Table 1 . The user response analysis is measured by the Likert fourchoice scale with scoring guidelines in Table 2 . The formula used in calculating the percentage of user response scores using the formulation by Yamasari (2010):

$$
\mathrm{R}=(\mathrm{f} / \mathrm{n}) \times 100 \%
$$

Explanation:

$\mathrm{R}=$ Percentage of respondents score $(\%)$

$\mathrm{f}=$ Number of scores obtained

$\mathrm{n}=$ Maximum score

The percentages obtained are then converted to qualitative values with the validity criteria in Table 3.

\section{RESULT AND DISCUSSION}

This research development produces interactive emodule Chemistry Magazine products for ionic equilibrium and $\mathrm{pH}$ of buffer solution and solubility equilibrium materials. This product can be accessed via electronic media such as a computer, laptop, Android, iPhone, iPad, and other technology both online and offline. Teachers and students can use the interactive e-module Chemistry Magazine during the learning process in the classroom and as self-teaching materials even not in lesson time. Here is the exposure of results and discussion of each development phase that has been done. Research stages using the Plomp model include the initial investigative phase, design phase, realization/construction phase, validation, trial, and revision phase, and the implementation phase. The explanation of the results of each stage of development, as follows:

\subsection{The Initial Investigation Phase}

Front End Analysis, Information and data obtained from the analysis of the front end is a little source of learning that also can generate interest and motivation of the learners, and it can help the learners to connect with the material that has been learned in daily life. The teaching materials commonly used in the learning process is printed 
text materials in the form of textbooks, student worksheet, and copied task and digital resources in the form of powerpoint text (PPT). Analysis of the front end to some relevant literature, obtained the information that the chemistry subject is expected can bring the students to fill the $21^{\text {st }}$ century ability, one of that is, skilled in using media, technology, information and communications (ICT) (Kementerian Pendidikan dan Kebudayaan, 2016) and in the framework of teacher competence development in producing a paper which is intensified through movement of "Satu Guru Satu Buku (SAGUSABU)" by Directorate of Teacher and Education Personnel of Ministry of Education and Culture since 2016.

Student's Analysis, Characteristics of learners adjust with the design of the development product that has made. The results of the analysis of students showed that students at the second class of senior high school are in the range age of 16-17 years. Based on Piaget's cognitive development theory, on this age, the learners approach the maximum intellectual efficiency, but due to lack of experience thereby limiting their knowledge and skills to exploit what is known. Many things that can be learned through experience, but learners sometimes have difficulty in understanding of the abstract concepts (Piaget, 2001).

The result of the questionnaire is $100 \%$, the learner stated that the existence of the learning resource is considered important. As many as $85.54 \%$ of students find difficulties in learning chemistry subject, in this case, it's

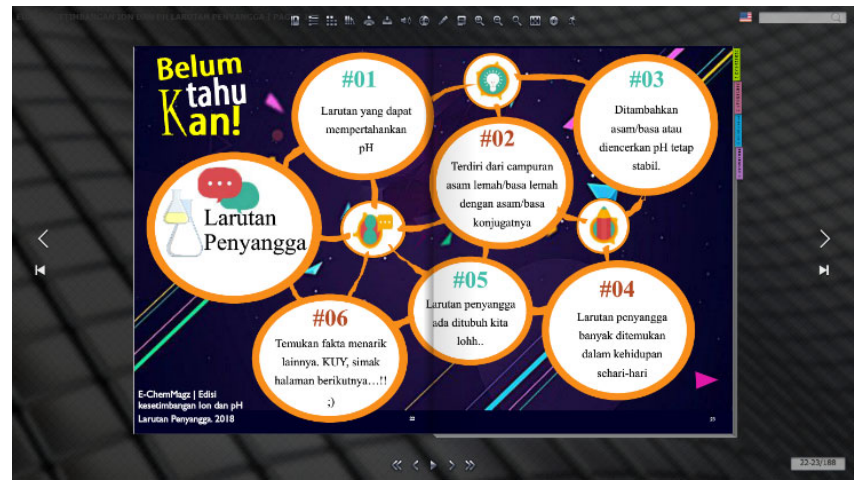

Figure 1 Examples of products in ionic equilibrium and $\mathrm{pH}$ of buffer solutions editions on material design part

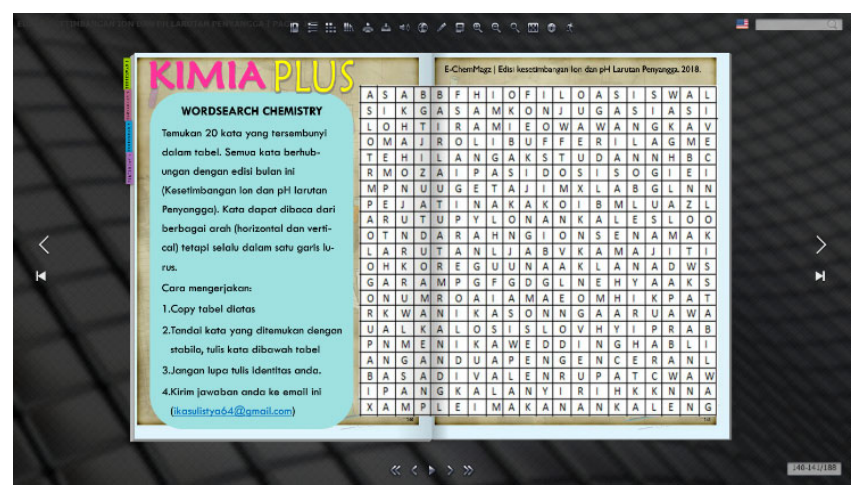

Figure 2 Examples of products in ionic equilibrium and $\mathrm{pH}$ of buffer solutions editions on magazine part because less of the learning resources that can help the learners to an understanding about the subject, therefore the existence of learning resources in this interactive emodule Chemistry Magazine is expected can help the learners in the learning process. It is also supported by the facilities for interactive e-module Chemistry Magazine that is $81.92 \%$ of students have PC or gadget to operate of interactive e-module Chemistry Magazine.

Material's Analysis, The results of interviews with chemistry teachers found that the material of ionic equilibrium and $\mathrm{pH}$ of buffer solution there are three main points; the nature of the buffer solution, the $\mathrm{pH}$ of the buffer solution and the function of the buffer solution in the body of living beings and in daily life. Sub-material properties of buffer solutions are sub-material theories that require an understanding of the concepts that the learners must really understand because these sub-materials are the first sub-matter of the ion equilibrium material and the $\mathrm{pH}$ of the solution, as well as for the functions of sub-material buffer solution in the body of living beings and in daily life. The calculation of $\mathrm{pH}$ sub-material of the buffer solution is a calculation material involving some of the precursor material such as stoichiometry and acid-base. While in the material of solubility equilibrium, learners learn about the definition of solubility, the yield of the solubility product (Ksp), forecasting the formation of precipitate from mixing the ions with opposite charge, the influence of the same ion on the solubility of ionic solids in water, the factors that

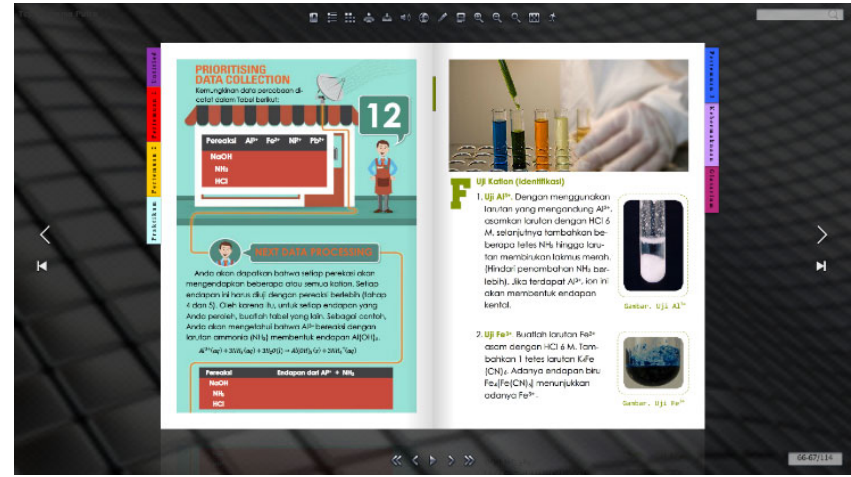

Figure 3 Examples of products in solubility equilibrium editions on material design part

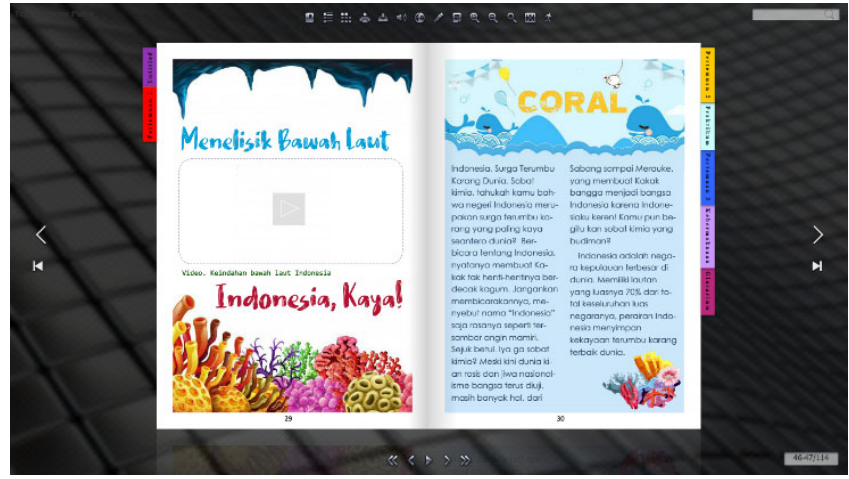

Figure 4 Examples of products in solubility equilibrium editions on magazine part 
affect the solubility, and selective precipitation (Watoni, 2014).

Competency Analysis, The ionic equilibrium, and $\mathrm{pH}$ of the buffer solution is one of the chemical learning materials found in the basic competence of 3.12 and 4.12 in the syllabus of chemical subjects of senior high school (Kementerian Pendidikan dan Kebudayaan, 2016). While the solubility equilibrium material is found in the basic competencies of 3.14 and 4.14. The results of the syllabus analysis will be obtained indicators of learning achievement and learning objectives to be achieved by learners.

\subsection{Design Phase}

The design phase is designed to design the initial product that will be developed in outline. The results of the design stage are; (1) the blueprint of interactive emodule Chemistry Magazine, (2) grid sheet validation of material experts and media experts and (3) design of user response questionnaires by teachers and students. The blueprint of interactive e-module Chemistry Magazine load e-module content according to Direktorat Tenaga Kependidikan (2018), that is; 1) Cover page, 2) Preface, 3) Table of contents, 4) Position map, 5) Description of content, 6) Benefits, 7) Instructions for use, 8) Concept maps, 9) Learning; which includes a) learning objectives, b) material description; composed of apperception, learning material, sample questions, formative tests; in the form of crossword and multiple choice puzzles, summaries, assignments, follow-up, magazine content; in the form of scientific articles, tips, galleries, and profile figures, 10) Evaluation, 11) Answer keys, 12) Glossary and 13) Bibliography.

\subsection{Realization or Construction Phase}

The results obtained in this phase are; (1) the prototype as the realization of the design result of interactive emodule Chemistry Magazine which is in accordance with the results of the analysis that has been carried out, the characteristics and structure of an interactive e-module, magazine content, and components of ICT-based teaching materials assessment, (2) the validation sheet of material experts and media experts refers to the guidance of developing ICT-based teaching materials by the Direktorat Pembinaan SMA (2010) and (3) user response questionnaires constructed in such a way as to the needs of the study.

\subsection{Validation, Trial and Revision Phase}

Validation aims to derive valuations and suggestions from a validator team consisting of a media validator and two material validators. Validation is done until the product developed in category valid. Some examples of products in ionic equilibrium and $\mathrm{pH}$ of buffer solutions editions can be seen in Figure 1 and Figure 2. As for the solubility, equilibrium can be seen in Figure 3 and Figure 4.

For the validation of the ionic equilibrium and the $\mathrm{pH}$ of the buffer, solution edition can be seen in Figure 5 and
Figure 6. As for the result of validation of the equilibrium solubility edition can be seen in Figure 7 and Figure 8.

Overall, the validation results show very good criteria, which means that the e-module Chemistry Magazine that has been developed has met the requirements set by the Direktorat Pembinaan SMA (2010) in the guide to the development of ICT-Based teaching materials that covering substance aspect, instructional design, display (communication visual) and software utilization.

The trial aims to derive user-side assessments and suggestions of teachers and students of interactive emodule Chemistry Magazine. Scores of respondents of ionic equilibrium and $\mathrm{pH}$ of buffer solution edition were obtained from teachers questionnaire sheet of $87.08 \%$ and $88.45 \%$ of students questionnaires. As for the solubility equilibrium edition, a percentage of $94.25 \%$ was obtained from the teachers and $91.43 \%$ from students. Based on Table 4 , the $75 \%-100 \%$ range is in the very good category, it can be concluded that the developed interactive e-

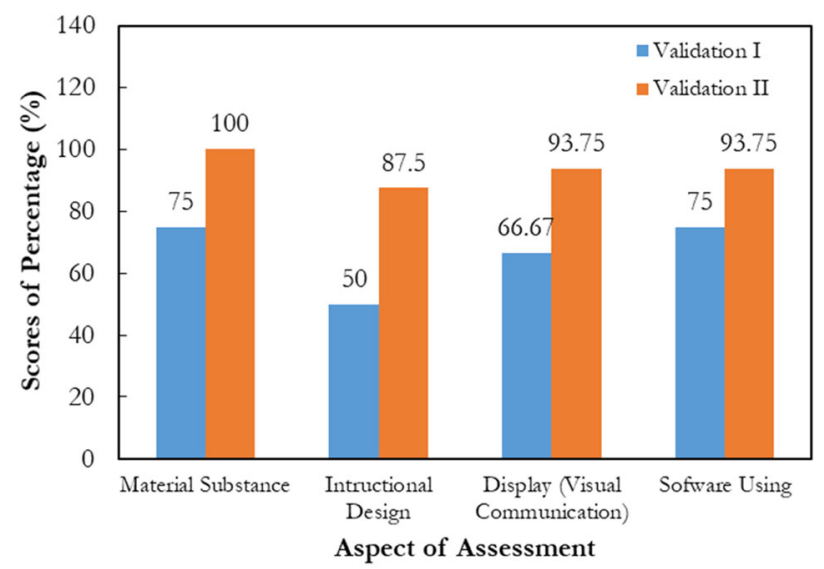

Figure 5 Comparison diagrams validation I and II by media experts the ionic equilibrium and the ph of the buffer solution edition

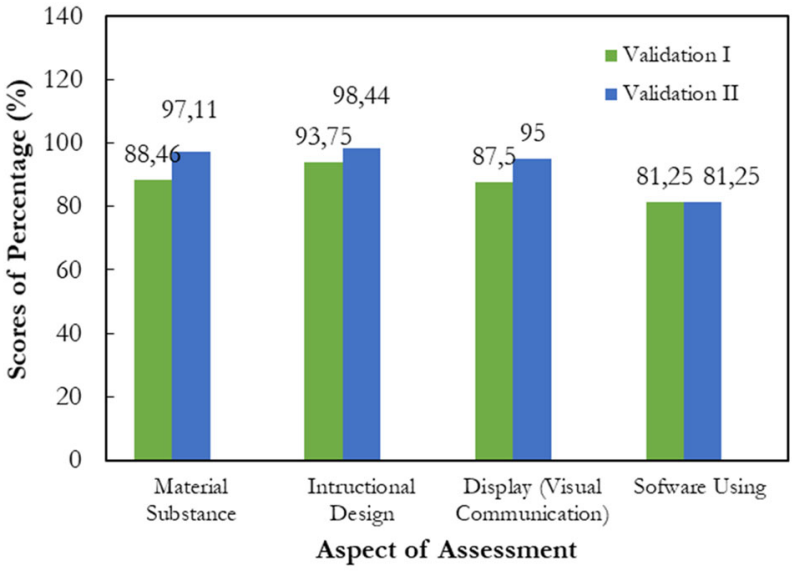

Figure 6 Comparison diagrams validation I and II by materials experts in the ionic equilibrium and the ph of the buffer solution edition 


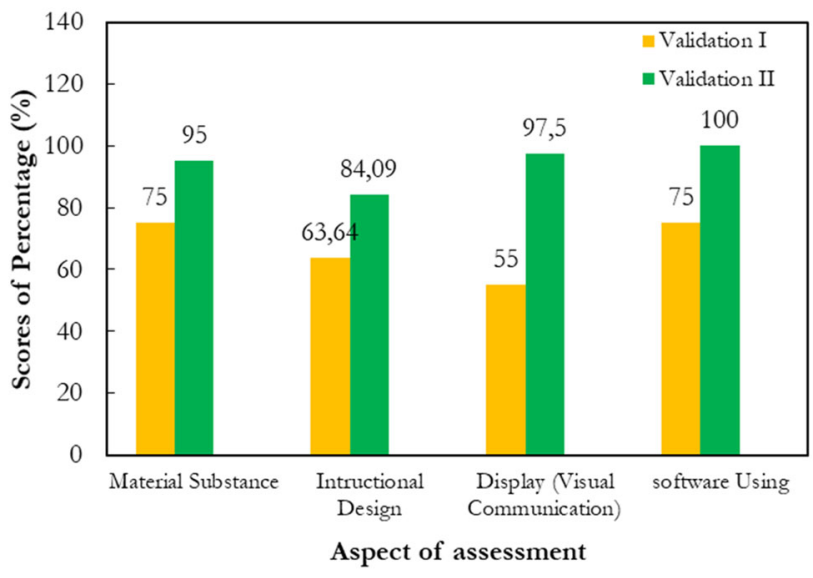

Figure 7 Comparison diagrams validation I and II by media experts in the equilibrium solubility

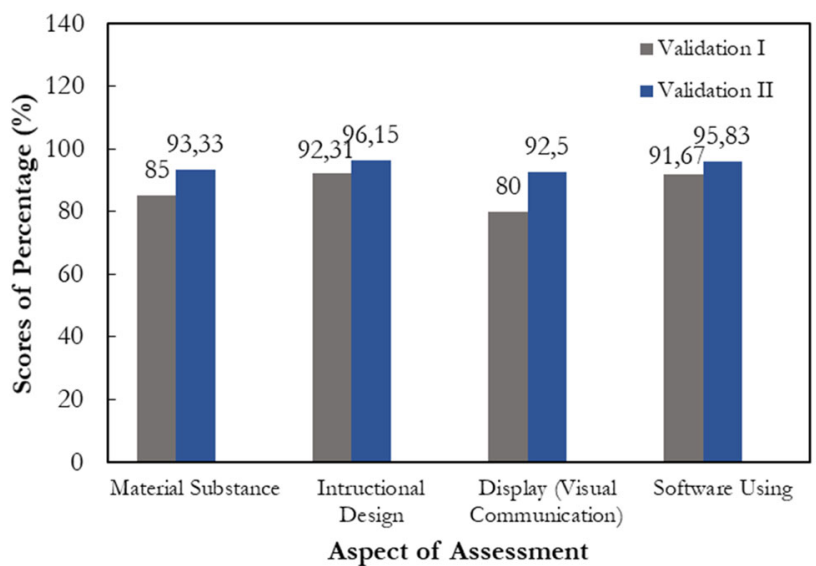

Figure 8 Comparison diagrams validation I and II by materials experts in the equilibrium solubility

module Chemistry Magazine is considered positive by the respondents and can be used in the learning process.

\section{CONCLUSION}

This research was conducted until the phase of validation, trial, and revision, which produced a learning product in the form of ICT-based teaching materials. The phases of the research that have been carried out involve investigating the target users of the product, designing, constructing and evaluating by experts to regarding the wetness of the material and the use of the media in the learning process.

The results of the research on the development of interactive e-module Chemistry Magazine of ionic equilibrium and $\mathrm{pH}$ of buffer solution edition and solubility equilibrium edition are valid by material validator with $a$ score of $93.75 \%$ and $94.45 \%$. While the media validator obtained a score of $91.70 \%$ and $94.18 \%$. The interactive emodule Chemistry Magazine is also rated very well by students and teachers with a percentage of $88.45 \%$ and $87.70 \%$ in ionic equilibrium and $\mathrm{pH}$ of buffer solution edition. While on an edition of solubility equilibrium obtained by percentage of $91,43 \%$ by teachers and $94,25 \%$ by students.

\section{REFERENCES}

Direktorat Pembinaan SMA. (2008). Teaching materials development guidelines (Panduan pengembangan bahan ajar). Jakarta: Kementerian Pendidikan Nasional Direktorat Jenderal Manajemen Pendidikan Dasar dan Menengah.

Direktorat Pembinaan SMA. (2010). ICT-based teaching materials development guidelines (Panduan pengembangan bahan ajar berbasis TIK). Jakarta: Kementerian Pendidikan Nasional Direktorat Jenderal Manajemen Pendidikan Dasar dan Menengah.

Direktorat Tenaga Kependidikan. (2008). Module writing (Penulisan modul). Jakarta: Direktorat Jenderal Peningkatan Mutu Pendidik dan Tenaga Kependidikan Departemen Pendidikan Nasional.

Kementerian Pendidikan dan Kebudayaan. (2016). Chemistry syllabus for high school (Silabus mata pelajaran kimia sekolah menengah atas / madrasah aliyah $S M A / M A)$. Jakarta: Kementerian Pendidikan dan Kebudayaan.

Kvisoft. (2015). Kvisoft Flipbook Maker. Retrieved from http://www.kvisoft.com/.

Piaget, J. (2001). The Psychology Of Intelligence. London: Routledge.

Rohmad, A., Suhandini, P., \& Sriyanto. (2013). Development of student worksheets based on exploration, elaboration and confirmation and disaster as geography subject learning materials for SMA/MA in rembang Pengembangan lembar kerja peserta didik (LKS) berbasis elesplorasi, elaborasi dan konfirmasi (EEK) serta kebencanaan sebagai baban ajar mata pelajaran geografi SMA/MA di Kabupaten Rembang. Edu Geography, 1(2), 1-5.

Rochmad, R. (2012). Design of mathematics learning tool development model (Desain model pengembangan perangkat pembelajaran matematika). Kreano, Jurnal Matematike Kreatif-Inovatif, 3(1), 59-72.

Syahrowardi, S., \& Permana, A. H. (2016). Multimedia handout design using 3D professional pageflip for learning media on android systems (Desain handout multimedia menggunakan 3D pageflip professional untuk. media pembelajaran pada sistem android). JPPPF (Jurnal Penelitian dan Pengembangan Pendidikan Fisika), 2(1), 89-96.

Syamsurizal, H., \& Chairani, N. (2015). Pengembangan e-Modul Berbasis Keterampilan Proses Sains pada Materi Kesetimbangan Kimia untuk Tingkat SMA. SEMIRATA, 2015.

Watoni, A. H. (2014). Chemistry for SMA/MA K11 (Kimia Untuke $S M A / M A$ Kelas XI (Peminatan). Bandung: Yrama Widya.

Wulandari, R., Azrita, \& Hendri, W. (2016). Development of teaching materials based on magazine-nuanced modules equipped with a glossary for K8 students at SMPN 12 Padang (Pengembangan baban ajar berbentuk modul bernuansa majalah dilengkeapi dengan glosarium untuk peserta didik kelas VIII di SMPN 12 Padang). Bung Hatta University, $5(7)$.

Yamasari, Y. (2010). Development of high quality ICT-based mathematics teaching media (Pengembangan media pembelajaran matematika berbasis ICT yang berkualitas). Seminar Nasional Pascasarjana X-ITS. FMIP A Unesa, 2010. 